\title{
Images of the Wilderness in some Elizabethan Gardens
}

Jane Avner

\section{(2) OpenEdition}

\section{Journals}

\section{Electronic version}

URL: http://journals.openedition.org/shakespeare/1286

DOI: 10.4000/shakespeare.1286

ISSN: 2271-6424

\section{Publisher}

Société Française Shakespeare

Printed version

Date of publication: 1 November 1995

Number of pages: 9-25

\section{Electronic reference}

Jane Avner, "Images of the Wilderness in some Elizabethan Gardens », Actes des congrès de la Société française Shakespeare [Online], 13 | 1995, Online since 01 January 2007, connection on 01 May 2019.

URL : http://journals.openedition.org/shakespeare/1286; DOI : 10.4000/shakespeare.1286 


\title{
SHAKESPEARE \\ LE MONDE VERT : RITES ET RENOUVEAU
}

Société Française Shakespeare

\author{
Actes du Congrès 1994 \\ sous la direction \\ de \\ M.T. JONES-DAVIES
}

Ouvrage publié avec le soutien de

BARCLAYS

BARCLAYS BANK S.A.

PARIS

LES BELLES LETTRES

1995 
Tous droits de traduction, de reproduction et d'adaptation réservés pour tous les pays.
(C) 1995 Société d'édition Les Belles Lettres, 95 bd Raspail 75006 Paris 


\section{Images of the Wilderness in some Elizabethan Gardens}

\section{(i) Introduction}

This paper has a double focus : in making some very modest proposals towards an understanding of the wilderness in the 16 th century garden, I shall be looking at both real and imaginary gardens, real and imaginary wildernesses. However as these terms are in themselves problematic I shall generally refer to gardens that really existed as being in situ, keeping imaginary for the more figurative gardens and wildernesses we encounter in Elizabethan texts.

Garden and wilderness were, of course, for a long time simply opposed to one another and, like other binary terms such as Nature/Art or Nature/Culture, with which indeed they could well be identified, they were often referred to in a manner which was, to a certain extent, mutually defining. However in the 16th century the wilderness came into the English garden in situ and it came to stay. This initial paradox was compounded by the fact that the garden in question was, as you know, of a highly formal nature. The fortunes of the wilderness have waxed and waned since then but it has continued to evolve within the space - mental and physical - of English gardens. (A recent literary example may be found for instance in V. S. Naipaul's very fine $A$ sense of Arrival, where the wilderness is an important structural element of the garden he describes there).

I shall begin by framing Elizabethan conceptions of the wilderness by taking a brief look at the early 18 th century as well as at a few key elements of pre-Renaissance notions of wildness which, as we shall see, influence Elizabethan representations of the wilderness in gardens. I shall then go on to analyse an Elizabethan wilderness in-situ and finally some textual images where I shall be talking about the wilderness in a rather more ex- 
Positioned within the garden the wilderness could, (it is by no means its only function) disrupt the smooth surface of the more classical configurations of its green and golden worlds. I am interested in these moments of disjunction, and in the virtual, or potential meanings that may be glimpsed in the space they figure. A propos, I would like to make my own a phrase used by Augustin Berque in his book Mediance. It comes from a rather moving passage in which he describes his encounter with a particular landscape in Japan which he learned was referred to as 'Les digues de brume', - (dykes, or breakwaters to catch or retain the mist). Although he was unable to trace the etymology of this term, which fascinated him, he describes this moment, (the coming together of a name and a particular topography) as a moment when, 'le paysage ... a fait sens', (the landscape made sense). «l'important c'était l'image, he writes, le passage qui s'ouvrit [...] entre un nom et un paysage». [The important thing was the image : the passage which it opened between a name and a landscape $]^{1}$. The etymology of the word wilderness is in no sense obscure, several columns are devoted to it in the OED, (although Elizabethan wilderness receives no mention it has to be said). I will return to the important question of the name in my conclusion. However I would like to suggest that with the wilderness as with the 'digues de brume', what matters is the image, the enjoining of a name to a particular topographical element in the garden, which, in more senses than one, opens a passage in the mental and physical space of the 16th century garden in England.

Our own notions of, and one might add, fondness for, the idea of wilderness stem from the 18th century which was to have such a profound influence on our conceptions of what gardens ought (and I use the word advisedly) to look like. It is quite difficult to envisage the idea of the garden in England other than through the great paradigm shift it underwent in the 18th century. It has become a kind a regulatory norm in our imaginations, the 'natural' (sic) configuration of the relationship that should pertain between art and nature.

The Earl of Shaftesbury, Anthony Ashley Cooper, was 
perceptions of the natural world, and incidentally to reorient our understanding of the wilderness. In The Moralists, (1709), he observed, astonishingly at the time, 'the Wildness pleases' :

We seem to live alone with Nature. We view her in her innermost Recesses, and contemplate her with more Delight in these original Wilds than in the artificial Labyrinths and feigned Wildernesses of the Palace ${ }^{2}$.

The words 'artificial' and 'feigned' invite comment positioning us as they do clearly within a problematics of mimesis where the wilds are the original, the source, a first Nature which is taken to be somehow truer or purer, than the feigned wilderness and artificial labyrinths, visibly deficient copies in Shaftesbury's eyes. I think we may presume that Shaftesbury was probably doing a little feigning himself here in so disingenuously mis-recognizing 16 th and 17 th century intentions. What Shaftesbury, - and he was quickly followed by Pope among others, - was doing in saying essentially that the wilderness ought to be more natural, more wild even, was in fact confronting one imitative project with another and finding the first wanting.

The designers of one of those feigned wildernesses would no doubt have been surprised that an artful wilderness was to be so summarily dismissed, and doubtless protested that Shaftesbury was missing the point. The 'wilds' Shafetsbury is referring to in this passage are, interestingly enough, the deserts of Egypt. The desert, whose image he is here rehabilitating, was the original biblical source of wilderness. As Hayden White has noted the Hebrew word $S h^{e}$ mâmâh, (meaning desolation) was used both for a mental state and a place ${ }^{3}$. It is this term which is employed in the, frequent biblical comparisons between the garden and the wilderness: 'For the Lord shall comfort Zion', we read for example in Isaiah, $51 \mathrm{v}$. 3 , 'he will comfort her waste places, and he will make her wilderness like Eden, and her desert like the garden of the Lord'.

The desert was to remain a frequent wilderness image in southern Europe, the forest, - all those mazy forests of error so common to medieval and Renaissance Romance, - being the predominant image in northern Europe. The inhabitants of those dark woods are of course, the wild folk, whose story Richard Bernheimer has told so compellingly in his seminal study, Wild Men in the Middle Ages. As he, Timothy Husband in the magnificent catalogue he prepared for the exhibition The Wild Man (New 
York, 1980) and Dudley and Novak's very useful collection of essays The Wild Man Within ${ }^{4}$ have all shown, wildness has a long, complex and fascinating history. There can of course be no question of attempting to resume it here. However I would like to draw attention to a couple of motifs which illustrate one, and only one aspect of the gradual and very profound exchanges between 'wild' and ordinary folk. The wild man and wild woman and notions of wildness in general, were of course, intimately bound up with the figuring of desire. Indeed one of the images shown at the Metropolitan exhibition was of a wild man who is also a knight named Desire, leading a very forlorn young squire, his victim, to the Castle of Love. Far less terrible than this one were the enormous number of Castles of love being stormed by knights which featured in civic pageants, in manuscript illustrations and as a decorative motif on everyday objects such as mirrors, plates etc. Husband notes that this was probably the most popular allegorical motif appropriated by the wild man. In the latter part of the Middle Ages a number of representations show that the knights have been replaced by wild men and the ladies in question do not generally appear to be putting up too strenuous a resistance. Armorials (of which there were an increasing number showing wild men and women as the Middle Ages advanced) are a particularly succinct expression of the way motifs of wildness had penetrated the chivalric tradition. A glance at Papworth's Ordinary of British Armorials revealed that a very considerable number of families whose arms feature wild men or women, are called Wood.

II

Thanks largely to the Parliamentary Surveys we know rather more about 17 th wilderness than we do about those which, though perhaps less numerous undoubtedly existed in the 16th century. One of the earliest wildernesses to be created in England was almost certainly that of Nonsuch in Surrey. Constructed by Henry VIII between 1538 and 1547, at the moment that concerns us here, the palace belonged to John, Lord Lumley, who made extensive changes to the gardens between 1579 and 1591. Lumley had visited Italy in 1566 where he had been able to see the art and architecture of the Italian Renaissance and without doubt, its magnificent gardens at first hand. The wilderness he was to create

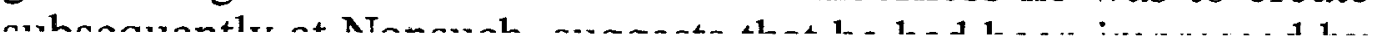


the boschetti which were such a distinctive feature of the Italian garden. The period at which it was created furnishes a key to interpreting its iconographical programme. One of the focal points of this wilderness was the grove dedicated to Diana, moon goddess, virgin huntress and Roman goddess of wild nature. You will of course already have guessed that the contemporary Diana whom Lumley was complimenting was Elizabeth, and indeed several pinnacles, one of them bearing her phoenix stood near by. Roy Strong has noted this and given a very clear and detailed account of the grove itself 5 .

In his discussion of The Faerie Queene, Jonathan Goldberg has spoken of the social realities which informed the production of Spenser's poem, and other Elizabethan texts. 'Not the least of these', he writes, 'were the courtly fictions that surrounded Queen, Elizabeth and which had to be and inevitably were in the text if the poet were to find favour with his monarch. In such a framework she is the end of his desire, its instigator as well, and that is no fiction' 6 . This is, I would suggest, as true of the 'text' of the garden as it was of other kinds of text. Elizabeth was represented (or represented) and celebrated in the gardens in which she was received during her progresses each summer, many of which had been created or transformed with such occasions in mind. She became at this moment their 'ideal reader'. Diana was but the latest of a number of roles elaborated by and for the Virgin Queen and her inscription in the Nonsuch wilderness was therefore a topical one. But the question we might well ask ourselves is whether Diana/Elizabeth's presence in Lumley's garden is purely celebratory?

Our knowledge of the wilderness comes from a variety of sources including that of Antony Watson, the curate of Cheam and an employee of Lumley. The wilderness itself inspired some of Watson's most lyrical flights of fancy - he writes ar length for instance about the question of the name ${ }^{7}$. His account stands alongside that of foreign visitors such as Thomas Platter - and it is to his record of the inscriptions that we shall refer in a moment. I shall only focus on the grove of Diana itself which was situated in a small dell where there was a natural spring. It would have been this natural source which fed the fountain and its basin, which were surrounded by rocks and a sculptural group showing Diana and the metamorphosis of Actaeon. Elswhere in the garden 
Diana/Elizabeth is associated with the moon and with "great creating nature' ; here in the wilderness it is the inherent eroticism of wildness which is developed : the virgin huntress pursued by a type of wild man, the hunter, Actaeon. Bernheimer has traced the evolution, an extremely fascinating one, of a wild woman pursued by a male demon, in a number of cultural traditions up to and including its medieval incarnation in Diana, 'wild woman', 'mistress of the wild horde'. Whilst the hunt is an obvious emblem of the metonymy of desire, the scene which confronted the visitor in the wilderness at Nonsuch catches an image of desire which is, of course, forever, suspended. Actaeon is perpetually in the process of becoming that other, the stag, of passing from one state of wildness, the hunter, to another, the hunted. Elsewhere in the gardens, other 'animals' - in topiary - mimed this arrested moment, through 'leaps' that were so convincing that many a visitor mistook them for real. Evidently such visitors were not encouraged to be idle spectators of the scene ; to the 'text' of the sculptural group itself, Lumley had enjoined others : a number of Latin inscriptions inciting one to meditate the dire consequences of a concupiscent regard. These were to be found at the entrance to the grove, on the walls of an arch leading out of the grove and into an orchard, and in a bower or small temple or banqueting house, (the accounts are conflicting, John Dent - The Quest for Nonsuch - opts for summer house) which was situated near by. Seated in this summer house, from which he could contemplate the metamorphosis the visitor could reflect on the counsels offered by the three texts engraved on the walls, and indeed, as they required, on his own moral situation as spectator.

On the gate leading into the grove Actaeon's plea to have his human head restored : "Against her who is unjust I demand my proper flesh', was met with Diana's adamant refusal : 'Actaeon, yours is a stag's heart, why should there not be horns? Your heart', she tells him 'is that of a beast'. In the summer house the goddess of virtue warns of the consequences of 'an evil mind'. The visitor was urged to be an active reader rather than a passive spectator :

Do not in the shade.

Be quiescent ;

Nor let there be to the one who is sitting

The eyes of the serpent ${ }^{8}$. 
Another text warns, 'the eyes of the ungrateful mind are impure'. As several critics have noted the counsels were susceptible to both political and moral interpretations. In his moralized Ovid's Metamorphoses Englyshed, George Sandys explains (and the interpretation was common) that the fable was invented to show that curiosity is dangerous : one should avoid looking into the secrets of Princes lest one discover their nakedness, and provoke their hatred. One would then be condemned to live the life of a wild stag, haunted by fear and suspicion [...]. Nobody could claim in this respect that Lumley was lacking in irony: he received the Queen frequently at Nonsuch, but she had little reason to trust him : he had, after all, been involved in several plots to overthrow her and restore a Catholic monarchy.

However in addition to the moral and political interpretations we have just alluded to one might well read, in these texts, the 'unquiet' representation of a social reality outside the garden with which the male subject of the Virgin Queen had to contend. The story of Diana and Actaeon is, as Lumley was at pains to point out, all about looking. The Nonsuch wilderness version is, I suggest, a copious development of this visual encounter. It is one which is fatal to Actaeon : as notions of the wild as 'other' are reinscribed he becomes first the victim or object of Diana's gesture, as she sprinkles him with water, and then the prey of his own dogs.

The metamorphosis which the visitor would have contemplated in the Nonsuch wilderness announced this, incipient, dismemberment. It is of course precisely this moment of passage - which at one and the same moment creates and dissolves identities, subject and object positions - which constitutes the fascination of metamorphoses. It is a moment which claims its proper space, a space which demands one might say to be recognized in and for itself. This is I feel what Pierre Kaufmann is doing when, in his L'Expérience Emotionnelle de l'Espace he speaks of the fantastic image of a bird with a woman's head : «[...] elle retient en elle», he says, "cette "altération", ce devenir-autre.»" [ She sustains within herself - this alteration, this 'becomingother" ...»].

The look which initiates the reversal of meaning between Actaeon and Diana is far from being the only one, however, to be mise-en-scène in this grove. The spectator's is also, and indeed,

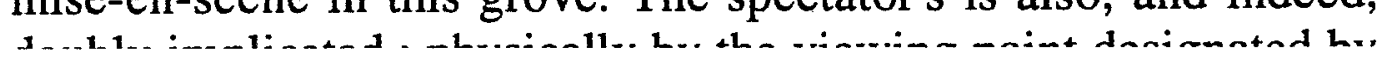


the summer house itself, and imaginatively through the various textual inscriptions which, in soliciting his attention, suggest several points of view, several ways of looking at the scene. In addition to the moral and political viewpoints touched on I would like to suggest another which derives from the very particular spatial dimension of metamorphoses which we have just referred to, as well as the inherent criticism of this particular one and its positioning in the 'wild' space of the garden. The image of this moment of alteration, of uncertain or multiple identities refracted in the incessant spray of the Nonsuch fountains, haunts neo-platonic Renaissance discourse when the Petrarchan beloved is associated, as Philippa Berry has reminded us with the Roman goddess $^{10}$. Through her identification with matter, with the natural world, by her 'wildness' in fact, she escapes the discursive constraints of the male subject/poet. From the 1580's onwards, Elizabeth, who had for many years, knowingly played with the language of desire, was, as we know, increasingly represented as Diana. Between absolute monarch and subject, desire is never, of course a symmetrical affair ; even less so when the - female sovereign in question wielded a patriarchal power. The mise-enscène of the consequences of the regards exchanged in the Nonsuch wilderness, seem in several senses to be paradigmatic of more threatening aspects of the social reality beyond the 'green world' : reminding the visitor here that there was 'a darker side to the Moon'.

That the eye may not come 'innocent' to its work, the perceptual spaces of Lumley's wilderness framed, variously, that which the metamorphosis claims for itself. Actaeon's divided, or perhaps more accurately double self, gestures beyond the wilderness to those of other Elizabethan subjects, including Lumley himself. It is a space well-fitted to figure the virtuality of those subject-selves, poised between symbolic dis-memberment and the desire to be re-membered by the Queen. My use of the terms 're-membered' and 'dis-membered' is indebted to Nancy Vickers suggestive essay 'The Body re-membered : Petrarchan lyric and the strategies of description' in which she discusses the corporeal scattering (spargere) of the Petrarchan lover and lady) ${ }^{11}$. A somewhat less dualist vision of metamorphoses than this implies though, would be to suggest, with Pierre Kaufmann, that they figure an 'other' which retains, holds in tension its several,

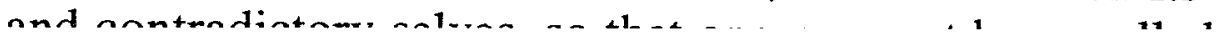


celled by the other ; that they propose, in other words, a less determinate space, in which the conaturality of wildness and civility may be envisaged. It is the simultaneity with which these selves are discovered or disclosed to the onlooker which constitutes the - singular - force of their sculptural incarnation. Bernheimer has described the numerous ways a chivalric, courtly tradition sought to appropriate the wild man's energies. Inscribing the wilderness within the garden might be envisaged as an attempt to capture, to throw into tension, the distinctive energies of the two orders of nature, in a language, only the 'erected wit' of man could deploy. Metamorphoses might be described as falling into two major groups: those which are in some senses liberating and those which are experienced as a punishment and are a kind of emprisonment. If Actaeon's is naturally traditionally classed with the second we might plausibly infer, given Lumley's insistence on the multiple points of view his wilderness frames, that the gaze the visitor might have shared with the 'wild man' figured here is also, in several senses, liberating. 'Une métamorphose', is, after all, as Philippe Quéau has observed, 'l'extériorisation d'une intériorité' : it allows one to glimpse, what he calls 'les rêves tus et inassou$v_{i s}{ }^{\prime 2}$. [A metamorphosis is the exteriorisation of an interiority ... that of unfulfilled or silenced dreams].

Lumley's wilderness was, I suggest, an elaborate conceit about looking and desire, though I suspect that the wilderness dissimulated within the more orthodox text of his garden designs, might well have been the desire to look upon another, or indeed other Queens. (In this he would not have been alone - other subjects, notably Sir Thomas Tresham, drew within their gardens; topographies of desire which were, pointedly not directed to the self-styled English Virgin Queen). In any case the explicitly Elizabethan configuration of Lumley's grove lends, it has to be said, a certain piquancy to the crossing of the political and sexual narratives ; the sexual voyeurism of which Actaeon stands accused being unexpectedly reaffirmed by the political allegory: the contemporary Prince whose secrets should not be too closely regarded being, after all, a woman.

The glances exchanged between Actaeon and Diana are but the first of the multiple visual trajectories (and we have by means mapped them all) traced in this grove. These might be thought of as being in turn, enclosed or overseen by the omniscient reader, 
she whom John Davies was soon to describe as 'The Eye of the Garden'13.

\section{III}

As the rather pedestrian verse inscribed over the entry to the wilderness at Sir Nicolas Bacon's gardens at Gorthambury (which I am pretty well certain pre-dated the Nonsuch one) makes clear, one of the mimetic joys which attached to this part of the garden was the imposing of order, the celebration of that 'heavenly art' which 'smooth'd ... the rugged frame' of untamed nature. (I quote from the Gorhambury insciption). Whenever the wilderness is evoked in the 16th century, questions of control and the rightful ordering of desire are never far away, and, as you know, this is a very predominant concern of Elizabethan discourse.

Shakespeare refers to the idea of 'wilderness' on a number of occasions, sometimes through the figure of 'unweeded gardens', the best remembered of these being perhaps the Duke of York's garden in Richard II bringing together questions of political and sexual desire Hamlet too speaks of the state of Denmark as an 'unweeded garden' and, in the same speech compares Claudius to that kinsman of the wild man, a satyr, and laments that his mother is less worthy than 'a beast that wants discourse of reason'. Significantly he refers to himself as less than Hercules. Hercules not infrequently figures as an, idealised, type of wild man, such as Orlando proves himself to be in his successful combat against Charles, the Duke's wrestler. 'Now Hercules be thy speed young man', prays Rosalind as, watching Orlando's physical prowess, she falls in love with him. Ariosto's Orlando Furioso was to inspire a number of imitations, including one of the most singular gardens ever created - Orsini's Sacro Bosco at Bomarzo. This is certainly one of the most complete treatments of the wilderness theme in a garden in situ (but the idea of an 'artfully' ruined garden reappears in the 18th century in such gardens as the Desert de Retz for instance). Shakespeare's Orlando displays a number of attitudes of a qualified kind of wild man and at the beginning of the play we find him complaining of the nurture/culture he has been denied. However as $\boldsymbol{A} \boldsymbol{Y L I}$ is structurally organized around a number of inversions, not the least of which is the spatial ordering of civility 
who will be so framed in the 'earthly paradise' tableau in Act IV, composed of the ancient tree, the green snake, and the old Adam, the wild man himself. Given the disorder in the courtly space (frequently referred to as 'inland', it is natural that the action should quickly shift to the more marginal space of the wilderness. If, aside from the emblematic Edenic scene we have just referred to, the Forest of Arden bears little resemblance to a garden in the strict sense of the word we quickly become aware that it is in fact one of those no-where places where the idea of the garden (especially, here the earthly paradise) is mapped upon that of the wilderness and vice-versa. As with the rector of Cheam, digressing at length about the unsuitability of the word desertum for the Nonsuch wilderness (a part of the garden he says, deserted neither by princes, nor by a wide variety of exotically wild animals or birds), the 'uncouth desert' that Orlando offers to 'people' with the 'tongues' of his verses, turns out to be a pretty crowded place already. Though Orlando expects that 'all things had been savage here' and Duke Senior speaks of the 'churlish chiding of the winter's wind', he also notes that 'here we feel not the penalty of Adam'. Though the ordering of sexual desire, undertaken chiefly by that 'Mistress of Discourse', Rosalind herself, is distinctly ambiguous, the political desires that eventually bring the Lord of Misrule, Duke Frederick himself to the 'skirts of this wild wood', perish with his conversion by the hermit, leaving the rightful Duke and his followers to move back, rather regretfully one is given to understand, to the inland space of the court.

The mapping of the earthly paradise garden on the wilderness and vice-versa was of course a constant leit-motif in the 16th and 17 th centuries not least in colonialist discourse where the penetration of Virgin land, and Ralegh's description of Guiana is of course a particularly striking instance, was expressed in explicitly sexual terms.

Of course Elizabeth's own body was conventionally referred to as 'a gardein fo no smale grace' impenetrable to her enemies. I suggested earlier that Lumley rather wittily played with ideas of reversibility when designing the grove of Diana in his own wilderness. I shall close with what is, I suggest a particularly audacious literary instance of a wilderness being inscribed across a garden which wittily re-constructs the nature of that 'gardein of no smale grace'. I am referring to The Four Foster Children of Desire 
Whitehall in 1581, to mark the visit of the French ambassadors, in England, - yet again - to negotiate the marriage of Elizabeth with Alençon. It constitutes I think a kind of culminating point in what may loosely be regarded as a group of entertainments offered to Elizabeth between 1575 and 1581, in all of which either the real or imaginary spaces of the garden are invoked to figure the workings of Elizabethan desire. The spectacular Kenilworth progress of 1575, which contributed perhaps more than any other to the 'golden world' mythology that various hosts tried to re-create in the gardens of Elizabethan prodigy houses, the intriguing Woodstock entertainments a few weeks later, The Lady of May, given in Wanstead garden in 1578 and the FFCD may all, in one way or another be associated with the Earl of Leicester. Robert Dudley had, early on in his career (1561) adopted the persona of Desire which he would henceforth associate with that of the wild man, (a favourite role of the Queen's father). One could I think trace a progressive toughening in attitude in the ideas of wildness expressed through these Dudley personae, which range from an idealised version speaking from his wilderness at Kenilworth, through the far less tame and simple creature who emerges from Epping Forest in 1578 and whose discourse more urgently interprets the eroticism of the wild man but whose underlying text is no longer the same, to the dazzling conceits proffered by the four wild knights in 1581.

Commenting on William Empson's remark that the pastoral puts 'the complex into the simple', Louis Montrose, in an important essay, observed 'the pastoralization of the Elizabethan body politic puts the complex into the simple and puts public relationships of power into intimate relationships of love - a love that is variously spiritual, maternal and erotic' ${ }^{14}$. Elizabeth was, of course extremely fond of reminding her subjects of the maternal love she bore them and of assuring them that she could not possibly envisage a marriage which would leave them orphans, all the while encouraging the erotic suggestiveness of courtly fictions, on condition of course that the only woman to be desired was herself, in life as in fiction. It is precisely the inherent aporias of such a situation, of such protestations and indeed of the nature of desire itself, which are exposed with considerable verve and brilliance in the FFCD where the ambiguities which attach to the 'of' are fully exploited : the foster children in question being both desirous, 
herself. The text also plays of course with the double sense of 'foster', adopted child and forester, and there can be little doubt as to the nature and political convictions of the four knights of Desire, (foster and forester, adoptive and wild), who lay siege (there is much play with a siege engine rolled on to the tournament yard) to their Lady Beauty in her fortress. (You will recognize the reappearence of the motif of the wild men/wild knights scaling the castle walls to carry off their ladies). The wild knight once again becomes the vehicle for expressing a position of dissension, here ostensibly against the marriage project. Rather more audacious is the text inscribed within the dissuasive discourse intended both for Elizabeth and the French ambassadors which, I suggest, questions the very basis of Elizabethan configurations of desire through a representation of the 'original' locus of desire itself, the garden of Eden. The re-reading of the original garden, obliquely shadowed by these desirous knights ('as strong in nurture as they are weak in fortune') as well as that of Elizabeth's emblematic relation to the garden, is a dazzling tour de force. Couched in irreproachably epideictic language one garden seems to give on to another which in turn permits us to glimpse a third and so on ... in a vertiginous rewriting of the biblical garden. Having initially evoked her redeeming function as a 2nd Eve, (a reference of course to her appropriation of the Virgin Mary mythology which made of her kingdom a kind of 'supplement' of paradise) her place in the garden narrative appears to shift to that of the desired fruit, forbidden to everyone but especially to Alençon.

However it is with this second distribution of parts that we begin to notice a gap opening up in the text of this Elizabethan garden. The image we glimpse in this space is - quite simply devastating. It is an Eden, wittily, ingeniously ruined, a wilderness in all but name. We learn that Lady Beauty, with whom a complex network of feeding images has been associated throughout the 'shew' is not simply desirable but desirous, not just desirous but insatiable: ' $\ldots$ is there any hope to winne by famine such a forte as yeeldes continuall foode to all her foes ?' asks a page on behalf of the four sons of Sir Francis Knowles. He continues :

' $\ldots$ and though they feede not fat therewith, yet must they either feede thereon or fast, for Beawtie is the only baite whereon Desire bites, and love the chief restoritie that ladie 
than men can live without mindes : of all the affections that are, Desire is the most worthy to woe but least deserves to win Beawtie, for in winning his sainct, he loseth him selfe ...' 15 .

Here Beawtie's role in the 'garden' seems to hover suggestively between that of the serpent, luring man to eat of the forbidden fruit and the forbidden fruit itself, the eating of which can only lead to the demise of our desirous knights. In a dazzling display of verbal wit the text ingeniously enfolds the various versions of Elizabeth one within another, cleverly playing off the ambiguities of the various narrative positions from which she has been figured both as end and instigator of her knights' desire. In this Elizabethan mise-en-abyme of the garden, the four foster children of desire, or wild knights may fairly be said to have outwitted the Queen at her own game.

\section{IV}

In concluding I would like first to refer back to the question of the name. There is clearly something distinctive about the word wilderness compared to the names of other garden features such as fountains, parterres, raised terraces or, for that matter boschetti. It is tempting to feel much as Alice seems to have done in Through the Looking Glass when she tries to answer the Gnat's query about the insects names: 'What's the use of their having names ?' The Gnat, as you may remember replied that he couldn't say and added that 'further on, in the wood down there, they'd got no names'. Obviously the naming of wildernesses, whatever the form they may take, is intimately bound up with ways of looking and these are, of course, as our earlier citation from The Moralists bears out, a moveable feast. However dismissive the 18 th century was to be of earlier wildernesses there can be little doubt that what the Elizabethans themselves delighted in was their 'conceitful' nature, the very feigning Shaftesbury found so distasteful. Before the 16 th century, the wilderness was situated on the margins of the garden space, it was the frame in a certain sense which enabled the idea of the garden to exist as such. A number of critics have pointed to analogies, usually of a temporal nature, between the arts of garden and theatre. The scenographer Yannis Kokkos (Le Scénographe et le Héron), has emphasized the importance of margins to his 
Si un espace ne prend pas en compte ce qui ne se voit pas, il n'a aucune force de suggestion. Je fais toujours un décor à partir de ce qui n'est pas sur scène, car sur scène doivent se trouver, tous les éléments qui permettent d'imaginer ce qui se trouve hors de la scène. Mon travail commence par là, par la marge. ... Je pose ensuite la question : qu'est-ce qui du dehors va parvenir jusqu'à l'intérieur de la scène ? Le hors-scène me préoccupe toujours, car je n'aime pas que l'espace de la scène s'arrête ${ }^{16}$.

[When a space fails to take into account what is unseen it loses its suggestive potential. I always begin with what will not be on stage when designing a theatrical décor, as all the elements which allow one to imagine what is off-stage need to be suggested there. My work begins there, in the margin. Afterwards I ask myself : what elements from the outside will appear in the interior scenic space ? What is off-stage interests me a great deal as I do not feel that the scenic space itself should come to an abrupt halt.]

The wilderness which crosses the threshold into the garden in the 16th century, makes no pretence to imitate, (in the sense of merely copy), a reality outside the framework of the garden, but rather, through the suggestiveness of its name to figure a more playful relationship with that reality or, as Paul Ricoeur might say : 'd'ouvrir l'espace de la fiction'. In integrating the wilderness, and I am referring both to its textual and in-situ representations, the space of the garden itself unfolds in a manner which may be compared to the unravelling of the Moebian band or ribbon in the topology of desire described by Lacan and in which the hidden, or concealed space of desire is made apparent. In this, now continuous space may be drawn the, properly Elizabethan, topographies of desire. The fragmented identities of Actaeon figured in the Nonsuch wilderness, gesture toward the other, or under side of those social realities we call 'courtly fictions'. At Kenilworth, Woodstock, Wanstead and most of all perhaps at Whitehall where the garden trope is systematically, if playfully, disabled, in figuring the wilderness the male author/subject might reappropriate symbolically, an initiative which, in the world beyond the garden text, could be more problematic. In so far as they disturb, in thoroughly traditional modes it should be acknowledged, the 'classical' order, (the harmonious image of the garden in the Golden Age), the elements of the wilderness belong to the 'grotesque' or fantantin wranld Dut ne Diarra Knufmon has armad 
Si l'imagination fantastique en effet caricature la norme de la réalité, l'idéal caricature le fantastique et réaffirme dans le registre qui lui est propre l'ordre bafoué ${ }^{17}$.

[If the fantastic caricatures the norms of reality, the ideal caricatures the fantastic, reasserting in its own register the derided order.]

I have attempted to indicate here some of the ways in which the idea of the 16th century garden, its texture as such, is woven from strands belonging to these two orders.

Jane AVNER

\section{NOTES}

1. Berque, Augustin: Mediance: de milieux en paysages. Paris, Géographiques/Reclus, 1990, p. 23.

2. Cooper, Anthony Ashley: the Earl of Shaftesbury: The Moralists, London, 1709, p. 388.

3. White, Hayden: 'The Forms of Wildness : Archeology of an Idea', in Tropics of Discourse, Baltimore, The Johns Hopkins University Press, 1978, p. 159.

4. Bernheimer, Richard: Wild Men in the Middle Ages : A Study In Art, Sentiment and Demonology. Cambridge. Mass. Harvard University Press, 1952. - Husband, Timothy: The Wild Man. Medieval Myth and Symbolism, New York, The Metropolitan Musuem of Modern Art, 1980. - Dudley, Edward and Novak, Maximillian (eds.) : The Wild Man Within: An Image in Western Thought from the Renaissance to Romanticism. Pittsburg, University of Pittsburg Press, 1972.

5. Strong, Roy : The Renaissance Garden in England, London, Thames and Hudson, 1979, p. 66.

6. Goldberg, Jonathan: Endlesse Worke. Spenser and the structures of Discourse, Baltimore, The Johns Hopkins University Press, 1981, p. 127.

7. Watson, Antony, Brief and True Description of Nonsuch Palace, Trinity College, Cambridge, Ms. R. 7.22.

8. Williams, Clare: Thomas Platter's Travels in England, 1599. Translated and introduced by Clare Williams, London, Jonathan Cape, 1937, pp. 199 ff.

9. Kaufmann, Pierre : L'Expérience Emotionnelle de l'Espace, 
10. Berry, Philippa: Of Chastity and Power. Elizabethan Literature and the unmarried Queen. London, Routledge, 1989, p. 40.

11. Vickers, Nancy: 'The Body Re-membered : Petrarchan Lyric and the Strategies of Description', in Mimesis : from Mirror to Method, Augustine to Descartes. Lyons, John, D. and Nichols, Stephen G. (eds.), Hanover, University Press of New England, 1982, pp. $100-109$.

12. Quéau Philippe : Metaxu. Théorie de l'art intermédiaire. Seyssel, Editions Champ Vallon, 1989, pp. 181-182.

13. Davies, Sir John: Hymnes to Astraea, $\mathrm{N}^{\circ} \mathrm{VII}$, The Complete Poems of Sir John Davies (ed. Grossart, Alexander), London, Chatto \& Windus, 1876, vol. I, p. 135.

14. Montrose, Louis : " "Eliza, Queene of Shepheardes" and the Pastoral of Power', in English Literary Renaissance, vol. 10, Spring 1980, $\mathrm{N}^{\circ} 2$, p. 157.

15. The Four Foster Children of Desire, in Entertainments for Elizabeth I. Wilson, Jean (ed.), Woodbridge, D. S. Brewer, 1980, pp. 79-80.

16. Kokkos, Yannis : Le Scénographe et le Héron. Arles, Actes Sud, 1989, p. 18.

17. Kaufmann, op. cit., p. 263. 